Reprinted from Earthquake Prediction-An International Review

Maurice Ewing Series 4

Copyright (C) 1981 by the American Geophysical Union.

\title{
AN ASPERITY MODEL OF LARGE EARTHQUAKE SEQUENCES
}

Thorne Lay and Hiroo Kanamori

Seismological Laboratory, California Institute of Technology, Pasadena, California 91125

Abstract. The variation in maximum rupture extent of large shallow earthquakes in circum-Pacific subduction zones is interpreted in the context of the asperity model of stress distribution on the fault plane. Comparison of the historic record of large earthquakes in different zones indicates that four fundamental categories of behavior are observed. These are: (1) the Chile-type regular occurrence of great ruptures spanning more than $500 \mathrm{~km}$; (2) the Aleutians-type variation in rupture extent with occasional ruptures up to $500 \mathrm{~km}$ long, and temporal clustering of large events; (3) the Kurile-type repeated failure over a limited zone of 100-300 km length in isolated events; and (4) the Marianas-type absence of large earthquakes. Southern Chile, Alaska, Southern Kamchatka, and possibly the Central Aleutians are grouped in the first category. The Rat Island portion of the Aleutians, Colombia, Southwest Japan, and the Solomon Islands zones demonstrate the temporal variation of rupture length and multiple earthquake sequences that characterize category 2. The New Hebrides and Middle America have earthquake clustering on a more moderate scale, and are intermediate between categories 2 and 3 . Category 3 includes the Kurile Islands, Northeast Japan, Peru and Central Chile. Zones lacking large earthquakes (category 4) include the Marianas, Izu-Bonin, and large portions of Tonga-Kermadec. By loosely grouping each subduction zone into these categories and comparing the general range in behavior with a simple fault model, which is used in a numerical simulation, the parameters governing large earthquake development are clarified. Interpretation of the four categories in terms of asperity distribution and interaction permits some inferences of the nature of stress distribution in particular zones. Two factors appear to dominate in the development of large earthquake failure zones; the nature and degree of coupling on the fault contact, and the extent of lateral segmentation of the subduction zone by transverse stress barriers. Strong coupling and uniform stress distribution on the fault plane produces larger events, whereas more heterogeneous stress distributions produce smaller ruptures and temporal variation in rupture length. Segmentation of the subduction zone that may result in stress barriers affecting rupture length is produced by subduction of transverse structures such as aseismic ridges, and is reflected by submarine canyons and geometric variations in trench configuration.

\section{Int roduction}

The variations in rupture length of large shallow earthquakes around the Pacific reflect variations in mechanical interaction between subducting and overriding lithospheric plates. Numerous studies have shown that these rupture zones usually occur over discrete, non-overlapping segments of the convergent zone [Fedotov, 1965; Mogi, 1968a, 1969a; Kelleher, 1970, 1972; Sykes, 1971; Kelleher et al., 1973; Utsu, 1974; McCann et a1., 19801. Individual segments tend to fail over the same region in successive cycles of large earthquakes [Imamura, 1928; Kelleher, 1972; Ando, 1975; Fukao and Furumoto, 1979], though there are temporal variations in which a section of trench will fail in a single great event during one sequence, and in several smaller events during another [Ando, 1975; Sykes et a1., 1981].

The width of the lithospheric interface has been correlated with maximum length of rupture zones by Isacks et al. [1968] and Kelleher et al. [1974], with regions of broad interface contact having the longest rupture zones. The presence of topographic features on the subducted sea floor [Kelleher and McCann, 1976, 1977] and the presence of transverse features such as ridges, submarine canyons, or changes in the strike of the trench that indicate segmentation of the subduction zone [Mogi, 1969b; Vogt, 1973; Carr et a1., 1974; Kelleher and Savino, 1975; Vogt et al., 1976; Spence, 1977; Chung and Kanamori, $1978 \mathrm{a}, \mathrm{b}]$ modify the relationship between contact area and rupture length. Carr et a1. [1974] and Nishenko and McCann [1979] discuss variations in trench structure, volcanic activity, earthquake mechanisms and seismicity distribution that may reflect slab segmentation or variations in the nature of subduction along convergent boundaries. 
Blocklike behavior of the overthrust plate may also be important [Ando, 1975; Spence, 1977]. The presence of back-arc spreading has been shown to correlate with an absence of large earthquake ruptures [Uyeda and Kanamor1, 1979; Ruff and Kanamori, 1980], and is thus associated with low coupling and aseismic subduction.

Little is actually known about the stress distribution and failure process of large earthquakes. Some general inferences about the state of stress in subduction regimes have been made based on maximum rupture lengths in each zone. Kanamori [1971b, 1977] proposed that the degree of coupling on the fault plane is reflected in maximum earthquake dimensions, with strong coupling being manifested by very large rupture zones, and decoupling associated with the absence of large earthquakes. Kanamori [1971b] proposed a model of gradual thinning and weakening of the ocean-continent lithospheric boundary to account for the differences in coupling and maximum rupture area.

Few studies have been performed yielding any resolution of the detailed nature of stress distribution in subduction zones. Lay and Kanamori [1980] studied body waves and surface waves of recent large events in the solomon Islands in an attempt to resolve the stress distribution on the thrust plane. They suggested that body wave complexity can be used to infer the degree of heterogeneity of stress, particularly in conjunction with foreshock and aftershock analysis. Other efforts to elaborate on the nature of failure in large earthquakes have demonstrated the complexity of the rupture process. Relative timing of body wave arrivals has indicated the multiple rupture nature of some events as manifested in body wave complexity [Imamura, 1937; Miyamura et a1., 1965; Wyss and Brune, 1967; Trifunac and Brune, 1970; Nagamune, 1971; Fukao and Furumoto, 1975; Wu and Kanamori, 1973], while synthetic seismograms have been used in more detailed analysis of other complex events [Fukao, 1972; Chung and Kanamori, 1976, 1978a; Abe, 1977; Kanamori and Stewart, 1978; Stewart and Kanamori, 1978; Rial, 1978; Fukao and Furumoto, 1979; Stewart et al., 1980; Ebe1, 1980; Boatwright, 1980]. The more detailed combined analysis of body waves and surface waves includes events in the Solomon Islands, New Hebrides, Middle America, Japan Trench, and Kurile Islands. In general it has been found that the body wave moment and inferred body wave source area are smaller than the surface wave determinations, particularly for the multiple rupture events [e.g., Kanamori and Stewart, 1978; Boatwright, 1980] .

Kanamori [1978a] appealed to the asperity model to explain the complexity of large events. This mode1, an outgrowth of laboratory experiments on rock friction, was first proposed by Byerlee [1970] and further developed by Scholz and Engelder [1976]. They suggested that the two sides of a fault are held together by areas of high strength called asperities. The stress on the asperities is high relative to the average stress on the entire fault plane. The nature of the stress concentrations may be variations in geometric orientation or heterogeneities of the frictional strength of the contact zone. There should be a random distribution of stress concentrations of various scale lengths existing on any given fault. Localized slip occurs when the shear stress on the fault surface exceeds the yield stress of the asperities, and this slip is accompanied by increase of stress on stronger asperities. Various aspects of foreshock activity [Wesson and E1lsworth, 1973; Jones and Molnar, 1979; and Ishida and Kanamori, 1978, 1980 ] and preseismic quiescence [Kanamori, 1981] have been modeled utilizing these ideas. Interactions between adjacent zones of large asperities can induce triggering [Lay and Kanamori, 1980], and the development of large earthquake ruptures or multiple events. In this model we distinguish between multiple events (isolated triggered events) and multiple rupture events (complex body wave events) because the character of the failure process reflects the degree of asperity interaction. The interaction between asperities will clearly be a function of the nature of the stress distribution of a given region, as well as of the presence of stress barriers segmenting the downgoing slab along a subduction zone.

Kelleher et al. [1974] suggested that the size and frequency of large earthquakes would not vary substantially over geologically short time periods, since the interface geometry and regional parameters of the subduction process would not change over short periods. This suggests the validity of characterizing the short-term past and future seismic behavior by examining historic rupture characteristics. In the following sections the nature of large earthquake occurrence in each subduction zone shown in Figure 1 is categorized, and a simple fault model is analyzed to provide a format within which to discuss the regional behavior.

\section{Regional Characteristics}

An extensive review of published source studies, seismicity patterns, and earthquake catalogues of circum-Pacific subduction zones has been undertaken [Lay and Kanamori, 1981]. The motivation for this project has been to quantify the common and individual characteristics of large earthquake occurrence in the subduction zones. Particular attention has been paid to studies of body wave complexity and foreshock-aftershock sequences, which most directly reflect the stress distribution on the fault plane. A qualitative compilation of the observations is given in Table 1 , where the comments and numerical values are gross features of a particular zone, with substantial deviation from these values possible within that zone. For 


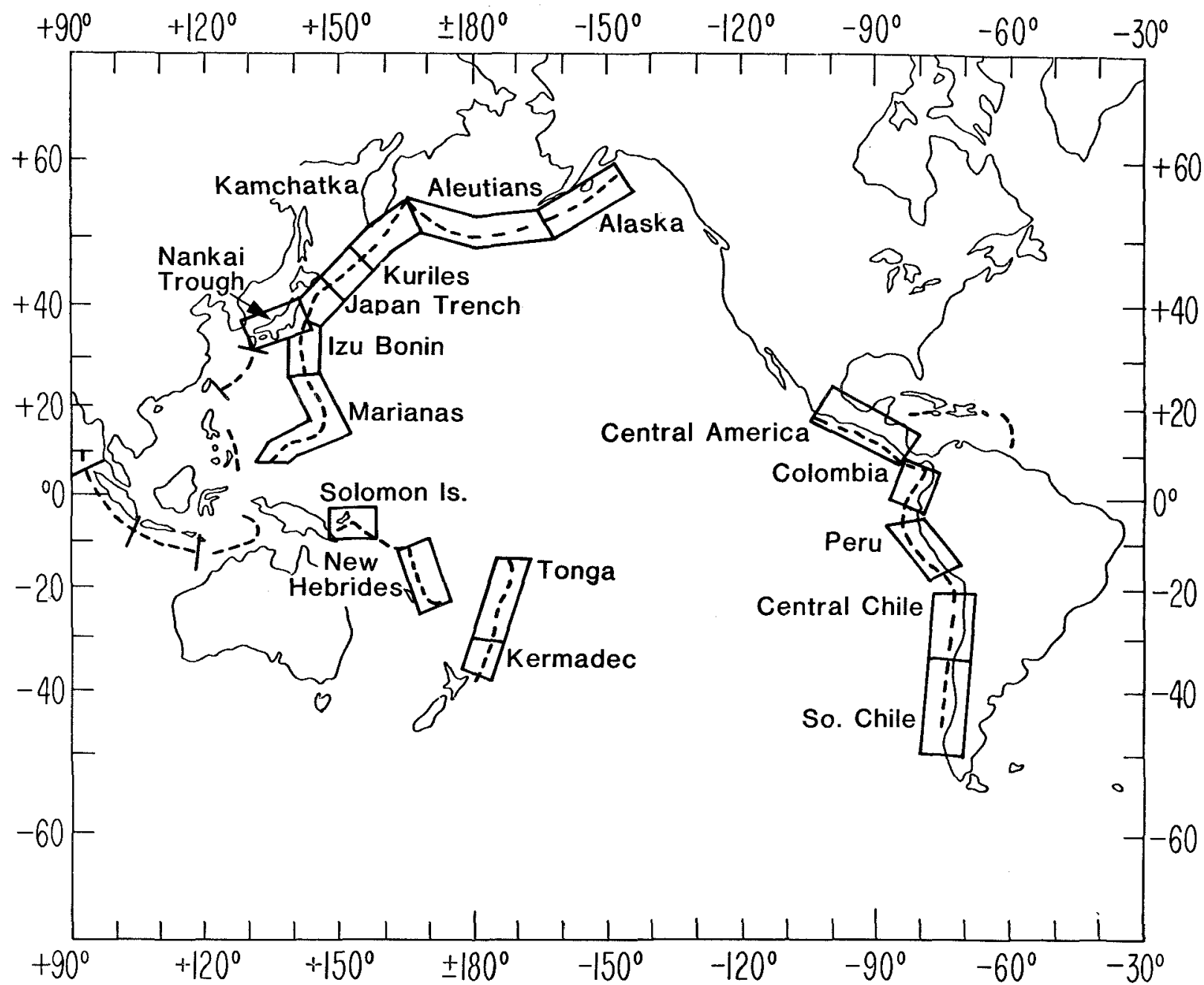

Figure 1. Map showing the circum-Pacific subduction zones considered in this study.

the purposes of discussion, we define 'great' earthquakes as having rupture lengths greater than $500 \mathrm{~km}$ long, and 'large' earthquakes as having rupture lengths of $200-500 \mathrm{~km}$.

On the basis of rupture length it is possible to divide the subduction zones into four basic groups, as shown in Table 2. Category 1 is exemplified by Southern Chile (Figure 2a), in which great earthquakes tend to recur regularly in time over approximately the same rupture zone. The 1964 Alaska and 1952 Kamchatka earthquakes occurred in regions which appear to have this mode of rupture. The historic record for the Central Aleutians, which failed in the 1957 event, is unclear [Sykes et al., 1981], but this area may behave similarly. These regions have a large percentage of seismic slip, though this is uncertain for Alaska (Table 1), and are inferred to be strongly coupled. The margins of these large rupture zones tend to abut large transverse features such as the Chile Rise and the narrowing of the plate interface south of Kamchatka.
Category 2 has smaller rupture dimensions as typified by the portion of the Aleutians which failed in the 1965 Rat Island event (Figure 2b). This region, as we11 as the subduction zones in Colombia, northern Kamchatka, and the Nankai Trough have demonstrated temporal variation in rupture mode, with occasional very large ruptures spanning segments of the trench that fail individually at other times. The Solomon Islands zone is grouped with these because of the frequent occurrence of large doublet events that are temporally and spatially linked.

Category 3 includes the Kurile Islands mode of failure (Figure 2c), in which large earthquakes repeatedly rupture the same portion of the subduction zone, but without coalescing to generate larger events. Peru, Central Chile, and the northern segment of the Japan Trench demonstrate Kurile-type behavior, although the length scale of the subzones ranges from 100-300 $\mathrm{km}$. The New Hebrides and Middle America zones have similarly sma11 rupture dimensions, but a 
Table 1. Characteristics of Circum-Pacific Subduction Zones Inferred from Large Earthquakes*

\begin{tabular}{|c|c|c|c|c|c|c|c|c|c|c|}
\hline Zone & $\begin{array}{l}\text { Rup ture } \\
\text { Lengths } \\
\quad(\mathrm{km})\end{array}$ & $\begin{array}{l}\text { Repeat } \\
\text { Times } \\
\text { (yrs) }\end{array}$ & $\begin{array}{l}\text { Se1smic } \\
\text { S1ip \% }\end{array}$ & $\begin{array}{l}\text { Sea Floor } \\
\text { Topography }\end{array}$ & $\begin{array}{l}\text { Transverse } \\
\text { Structures }\end{array}$ & $\begin{array}{l}\text { Anomalous } \\
\text { Foreshock- } \\
\text { Af tershock } \\
\text { Behavior } \\
-\end{array}$ & $\begin{array}{l}\text { Large } \\
\text { Normal Fault } \\
\text { Trench and } \\
\text { Tsumami } \\
\text { Events }\end{array}$ & $\begin{array}{l}\text { Contact } \\
\text { Width(km) } \\
\operatorname{Dip}\left({ }^{\circ}\right)\end{array}$ & $\begin{array}{l}\text { Body Wave } 1 \\
\text { Complexity }\end{array}$ & $\begin{array}{l}\text { Back- } \\
\text { Arc } \\
\text { Sprea } \\
\text { ing }\end{array}$ \\
\hline $\begin{array}{l}\text { Southern } \\
\text { Chile }\end{array}$ & $\sim 1000$ & $\sim 100$ & $75-100 \%$ & Smooth & $\begin{array}{l}\text { Bounded by } \\
\text { Chile Rise, } \\
\text { Some } \\
\text { canyons }\end{array}$ & $\begin{array}{l}\text { Extensive } \\
\text { foreshock. } \\
\text { activity just } \\
\text { before the } \\
\text { main shock }\end{array}$ & $\begin{array}{l}\text { Slow events } \\
\text { on Chile } \\
\text { Rise }\end{array}$ & $\begin{array}{l}200 \mathrm{~km} \\
10-20^{\circ}\end{array}$ & No record & No \\
\hline Alaska & $\begin{array}{l}100-200 \\
\text { along penin- } \\
\text { sula, } 800 \\
\text { in east }\end{array}$ & $\begin{array}{l}\text { Uncertain } \\
50-75 \text { in } \\
\text { west, >100 } \\
\text { in east }\end{array}$ & $\begin{array}{l}\text { Uncertain } \\
30-100 \%\end{array}$ & $\begin{array}{l}\text { Gulf of } \\
\text { Alaska } \\
\text { Seamounts }\end{array}$ & $\begin{array}{l}\text { Geologic pro- } \\
\text { vinces in } \\
\text { overthrust } \\
\text { slab }\end{array}$ & $\begin{array}{l}\text { Increased } \\
\text { preseismic } \\
\text { activity } \\
\text { near focus }\end{array}$ & No record & $\begin{array}{l}100-300 \mathrm{~km} \\
9^{\circ}\end{array}$ & $\begin{array}{l}\text { Complex } \\
\text { multiple } \\
\text { ruptures }\end{array}$ & No \\
\hline Kamchatka & $\begin{array}{l}500 \text { in south } \\
150 \text { in north }\end{array}$ & $\sim 108^{2}$ & $260 \%$ & Smooth & $\begin{array}{l}\text { Little } \\
\text { evidence }\end{array}$ & $\begin{array}{l}\text { Increased } \\
\text { preseismic } \\
\text { activity } \\
\text { near focus }\end{array}$ & No record & $\begin{array}{l}200 \mathrm{~km} \\
\text { Uncertain }\end{array}$ & No record & No \\
\hline Aleutians & $\begin{array}{l}\text { Temporal } \\
\text { variation } \\
100-1000\end{array}$ & $\begin{array}{l}\text { Uncertain } \\
\text { v60 in } \\
\text { west }\end{array}$ & $\begin{array}{l}\text { Uncertain } \\
\text { May be } \\
100 \%\end{array}$ & Smooth & $\begin{array}{l}\text { Changes in } \\
\text { strike, } \\
\text { canyons } \\
\text { ridges }\end{array}$ & $\begin{array}{l}\text { Some } \\
\text { foreshocks }\end{array}$ & $\begin{array}{l}\text { Large } \\
\text { tsunami \& } \\
\text { normal } \\
\text { fault events }\end{array}$ & $\begin{array}{l}150 \mathrm{~km} \\
15-20^{\circ}\end{array}$ & $\begin{array}{l}\text { Complex } \\
\text { multiple } \\
\text { ruptures }\end{array}$ & No \\
\hline Colombia & $\begin{array}{l}\text { Temporal } \\
\text { variation } \\
150-600\end{array}$ & $\begin{array}{l}\text { Variable } \\
36->73\end{array}$ & $\begin{array}{l}\text { Uncertain } \\
30-55 \%\end{array}$ & Smooth & $\begin{array}{l}\text { Little } \\
\text { evidence }\end{array}$ & $\begin{array}{l}\text { Little } \\
\text { foreshock } \\
\text { activity for } \\
1979 \text { event }\end{array}$ & No record & $\begin{array}{l}150 \mathrm{~km} \\
\text { Uncertain }\end{array}$ & $\begin{array}{l}\text { Complex } \\
\text { for } 1979 \\
\text { event }\end{array}$ & No \\
\hline $\begin{array}{l}\text { Nankai } \\
\text { Trough }\end{array}$ & $\begin{array}{l}\text { Temporal } \\
\text { variation } \\
150-300\end{array}$ & $170 \pm 70$ & $\begin{array}{l}\text { Uncertain } \\
70 \% 3\end{array}$ & Smooth & $\begin{array}{l}\text { Canyons, } \\
\text { terraces } \\
75-100 \mathrm{~km}\end{array}$ & No record & No record & $\begin{array}{l}100 \mathrm{~km} \\
10^{\circ}\end{array}$ & Uncertain & No \\
\hline $\begin{array}{l}\text { Solomon } \\
\text { Isl ands }\end{array}$ & $\begin{array}{l}\text { Doublets } \\
100-300\end{array}$ & $25-40$ & $50 \%$ & Smooth & $\begin{array}{l}\text { Woodlark } \\
\text { Ridge and } \\
\text { New Britain } \\
\text { Trench }\end{array}$ & $\begin{array}{l}\text { Few } \\
\text { foreshocks, } \\
\text { af tershocks }\end{array}$ & No record & $\begin{array}{l}<100 \mathrm{~km} \\
30-40^{\circ}\end{array}$ & $\begin{array}{l}\text { Simple } \\
\text { events, } \\
\text { Doublets }\end{array}$ & No \\
\hline
\end{tabular}




\begin{tabular}{|c|c|c|c|c|c|c|c|c|c|c|}
\hline $\begin{array}{l}\text { New } \\
\text { Hebrides }\end{array}$ & $100-200$ & $25-40$ & $\begin{array}{l}\text { Uncertain } \\
50 \%\end{array}$ & $\begin{array}{l}\text { Islands } \\
\text { Ridges }\end{array}$ & $\begin{array}{l}\text { D'Entrecas- } \\
\text { teaux and } \\
\text { East Renne1 } \\
\text { Ridges }\end{array}$ & $\begin{array}{l}\text { Foreshocks } \\
\text { for some } \\
\text { events }\end{array}$ & $\begin{array}{l}\text { Slow } \\
\text { events on } \\
\text { D'Entrecas- } \\
\text { teaux Ridge }\end{array}$ & $\begin{array}{l}<100 \mathrm{~km} \\
35-40^{\circ}\end{array}$ & $\begin{array}{l}\text { Sequences } \\
\text { of simple } \\
\text { events }\end{array}$ & Yes \\
\hline $\begin{array}{l}\text { Middle } \\
\text { America }\end{array}$ & $100-200$ & $\sim 35$ & $\begin{array}{l}\text { Variable } \\
10-100 \%\end{array}$ & $\begin{array}{l}\text { Fracture } \\
\text { zones \& } \\
\text { Ridges }\end{array}$ & $\begin{array}{l}\text { Large ridges } \\
\& \text { changes } \\
\text { in strike }\end{array}$ & $\begin{array}{l}\text { Moderate } \\
\text { foreshock } \\
\text { activity }\end{array}$ & No record & $<100 \mathrm{~km}$ & $\begin{array}{l}\text { Sequences } \\
\text { of simple } \\
\text { events }\end{array}$ & No \\
\hline $\begin{array}{l}\text { Kurile } \\
\text { Islands }\end{array}$ & $200-300$ & $\begin{array}{l}\text { Variable } \\
79->140\end{array}$ & $25 \%$ & Smooth & $\begin{array}{l}\text { Some } \\
\text { canyons, } \\
200 \mathrm{~km}\end{array}$ & $\begin{array}{l}\text { Many } \\
\text { foreshocks }\end{array}$ & $\begin{array}{l}\text { Frequent } \\
\text { ts unami } \\
\text { events }\end{array}$ & $\begin{array}{l}150 \mathrm{~km} \\
20^{\circ}\end{array}$ & $\begin{array}{l}\text { Complex } \\
\text { multiple } \\
\text { ruptures }\end{array}$ & No \\
\hline $\begin{array}{l}\text { Japan } \\
\text { Trench }\end{array}$ & $\begin{array}{l}150 \\
\text { decreasing } \\
\text { southward }\end{array}$ & $\begin{array}{l}100 \\
\text { (north) } \\
800 \\
\text { (south) }\end{array}$ & $\begin{array}{l}40 \% \\
\text { (north) } \\
5 \% \\
\text { (south) }\end{array}$ & $\begin{array}{l}\text { Seamounts } \\
\text { in south }\end{array}$ & $\begin{array}{l}\text { Canyons, } \\
\text { terraces } \\
100-200 \mathrm{~km}\end{array}$ & $\begin{array}{l}\text { Few } \\
\text { foreshocks }\end{array}$ & $\begin{array}{l}\text { Large } \\
\text { tsunami \& } \\
\text { normal fault } \\
\text { events }\end{array}$ & $\begin{array}{l}\sim 150 \mathrm{~km} \\
10^{\circ}\end{array}$ & $\begin{array}{l}\text { Sequences } \\
\text { \& multiple } \\
\text { source } \\
\text { events }\end{array}$ & No \\
\hline $\begin{array}{l}\text { Central } \\
\text { Chile }\end{array}$ & $\begin{array}{l}400 \\
\text { (north) } \\
200 \\
\text { (south) }\end{array}$ & 100 & $\begin{array}{l}\text { Uncertain } \\
>50 \%\end{array}$ & $\begin{array}{l}\text { Juan } \\
\text { Fernandez } \\
\text { Ridge }\end{array}$ & $\begin{array}{l}\text { Ridges, changes } \\
\text { in strike \& } \\
\text { dip of } \\
\text { Benioff zone }\end{array}$ & No record & No record & $\begin{array}{l}100-150 \mathrm{~km} \\
10-15^{\circ}\end{array}$ & No record & No \\
\hline Peru & 150 & $\begin{array}{l}\text { Variable } \\
100\end{array}$ & Uncertain & $\begin{array}{l}\text { Nazca } \\
\text { Ridge }\end{array}$ & $\begin{array}{l}\text { Nazca } \\
\text { Ridge }\end{array}$ & $\begin{array}{l}\text { Split } \\
\text { aftershock } \\
\text { zones }\end{array}$ & $\begin{array}{l}\text { Intermediate } \\
\text { depth normal } \\
\text { fault events }\end{array}$ & $\begin{array}{l}150 \mathrm{~km} \\
12^{\circ}\end{array}$ & $\begin{array}{l}\text { Complex } \\
\text { multiple } \\
\text { events }\end{array}$ & No \\
\hline $\begin{array}{l}\text { Izu-Bonin } \\
\text { Marianas }\end{array}$ & $\begin{array}{l}\text { No events } \\
\mathrm{M}_{\mathrm{s}}>7.4\end{array}$ & -- & $\begin{array}{l}\text { Uncertain } \\
\text { probably } \\
\text { very } \\
\text { smal1 }\end{array}$ & $\begin{array}{l}\text { Many } \\
\text { ridges, } \\
\text { seamoun ts }\end{array}$ & $\begin{array}{l}\text { Many } \\
\text { ridges, } \\
\text { seamounts }\end{array}$ & No record & No record & $\begin{array}{l}<100 \mathrm{~km} \\
\text { Uncertain }\end{array}$ & No record & Yes \\
\hline $\begin{array}{l}\text { Tonga } \\
\text { Kermadec }\end{array}$ & $<150$ & $\begin{array}{l}\text { Highly } \\
\text { variable }\end{array}$ & $\begin{array}{l}\text { Uncertain } \\
0-90 \%\end{array}$ & $\begin{array}{l}\text { Smooth } \\
\text { along } \\
\text { Tonga, } \\
\text { Loulsville } \\
\text { Ridge }\end{array}$ & $\begin{array}{l}\text { Louisville } \\
\text { Ridge }\end{array}$ & $\begin{array}{l}\text { Overlapping } \\
\text { aftershock } \\
\text { zones }\end{array}$ & $\begin{array}{l}\text { Large formal } \\
\text { fault events }\end{array}$ & $100-150 \mathrm{~km}$ & Uncertain & Yes \\
\hline $\begin{array}{l}{ }^{*} \text { Extracte } \\
{ }^{1} \text { As obser } \\
2_{\text {Based on }} \\
3_{\text {Based on }}\end{array}$ & $\begin{array}{l}\text { d from Lay a } \\
\text { ved on WWSSN } \\
\text { tsunami rec } \\
\text { convergence }\end{array}$ & $\begin{array}{l}\text { ong Peri } \\
\text { ds. } \\
\text { ate of } S\end{array}$ & $\begin{array}{l}\text { Seismogra } \\
\text { o (1977). }\end{array}$ & & & & & & & \\
\hline
\end{tabular}


Table 2. Subduction Zone Categories

\begin{tabular}{|c|c|c|}
\hline Category & Zones & Characteristics \\
\hline 1 & $\begin{array}{l}\text { Southern Chile } \\
\text { Southern Kamchatka } \\
\text { Alaska } \\
\text { Central Aleutians }\end{array}$ & $\begin{array}{l}\text { Regular occurrence of great } \\
\text { ruptures }(\geq 500 \mathrm{~km} \text { long). } \\
\text { Large amounts of seismic slip. }\end{array}$ \\
\hline 2 & $\begin{array}{l}\text { Western Aleutians } \\
\text { Colombia } \\
\text { Nankai Trough } \\
\text { Solomon Islands }\end{array}$ & $\begin{array}{l}\text { Variations in rupture extent, } \\
\text { with occasional ruptures } 500 \mathrm{~km} \\
\text { long. Close clustering of large } \\
\text { events and doublets. }\end{array}$ \\
\hline $2-3$ & $\begin{array}{l}\text { New Hebrides } \\
\text { Middle America }\end{array}$ & $\begin{array}{l}\text { Intermediate size and small } \\
\text { events with no great earthquakes, } \\
\text { but clustering of activity. }\end{array}$ \\
\hline 3 & $\begin{array}{l}\text { Kurile Islands } \\
\text { Northeast Japan Trench } \\
\text { Peru } \\
\text { Central Chile }\end{array}$ & $\begin{array}{l}\text { Repeated ruptures over limited } \\
\text { zones. No great events. Large } \\
\text { component of aseismic slip, or } \\
\text { subducting ridges. }\end{array}$ \\
\hline 4 & $\begin{array}{l}\text { Marianas } \\
\text { Izu-Bonin } \\
\text { Southeast Japan Trench } \\
\text { Tonga-Kermadec }\end{array}$ & $\begin{array}{l}\text { Large earthquakes are infrequent } \\
\text { or absent. Back-arc spreading } \\
\text { and large amounts of aseismic } \\
\text { slip are inferred. }\end{array}$ \\
\hline
\end{tabular}
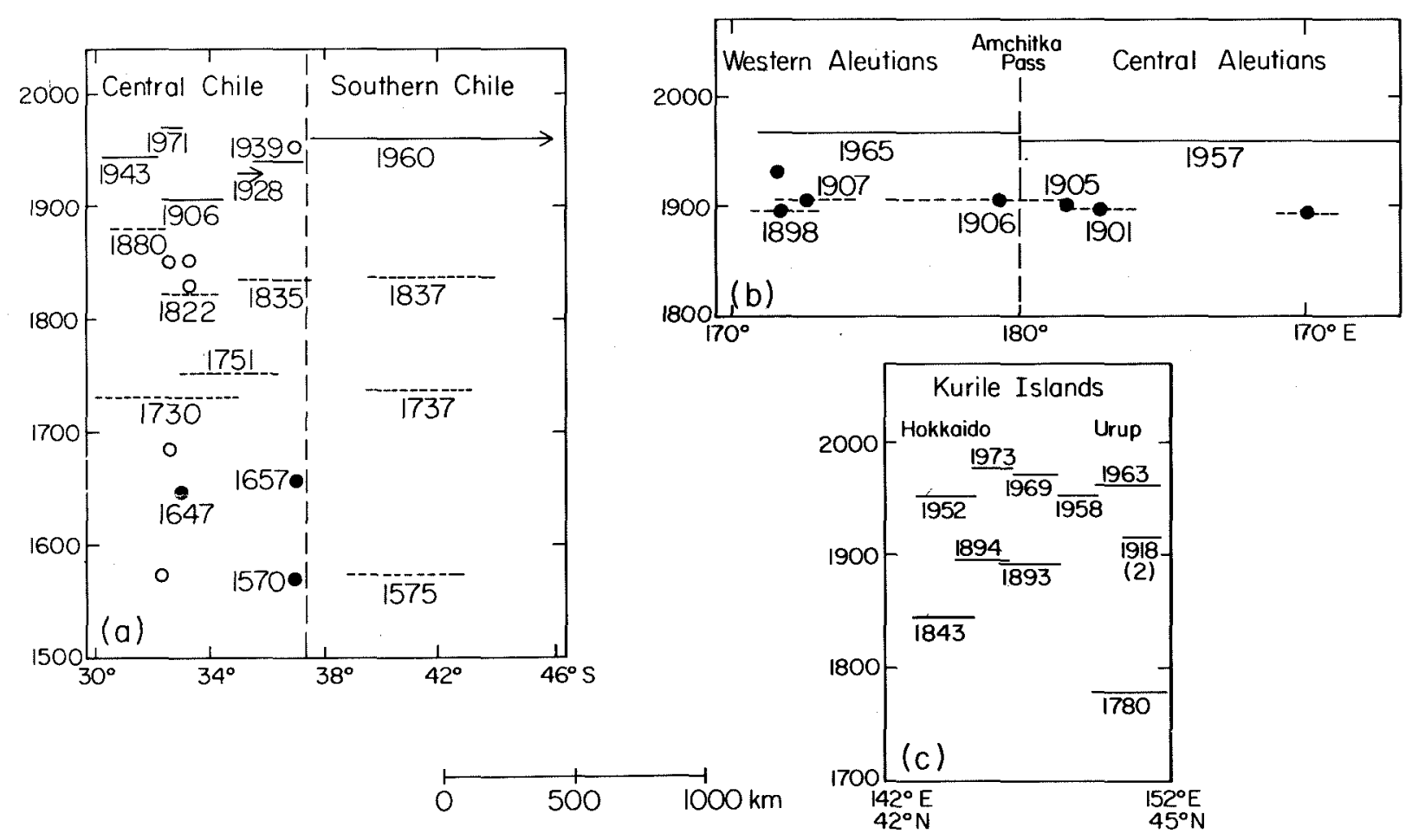

Figure 2. Historical records of large earthquakes in (a) Chile (after Stauder, 1972), (b) the Aleutians (after Sykes et al.,1981), and (c) the Kurile Islands. Inferred rupture extents are shown for events with adequate data. 
stronger tendency for events to cluster in time and space, indicating that they are intermediate between groups 2 and 3 .

Category 4 is characterized by the Marlanas-type absence of great earthquakes. The Izu-Bonin, southern Japan Trench and large portions of the Tonga-Kermadec zones are placed in this category. These particular zones are distinctive because of the presence of active back-arc spreading, and probably of a large component of aseismic slip.

\section{Asperity Model}

The regional characteristics discussed in the previous section can be modeled in terms of distribution and interaction of asperities. Aspertty size and distribution govern the degree of loading of adjacent asperities when a large asperity fails. The basis of this model is the analysis of earthquake doublets in the Solomon Islands [Lay and Kanamori, 1980]. As shown in Figure 3a, the individual rupture zones in the Solomon Islands are represented by a distribution of asperities. Failure of one of the asperities would cause an increase in stress on the adjacent asperities. In the Solomon Islands region, where the asperities are large and of similar size, these incremental stresses are large enough to trigger failure of an adjacent asperity, producing two or more distinct, but similar events in a sequence. For zones with more complex stress distributions (Figure 3b), the

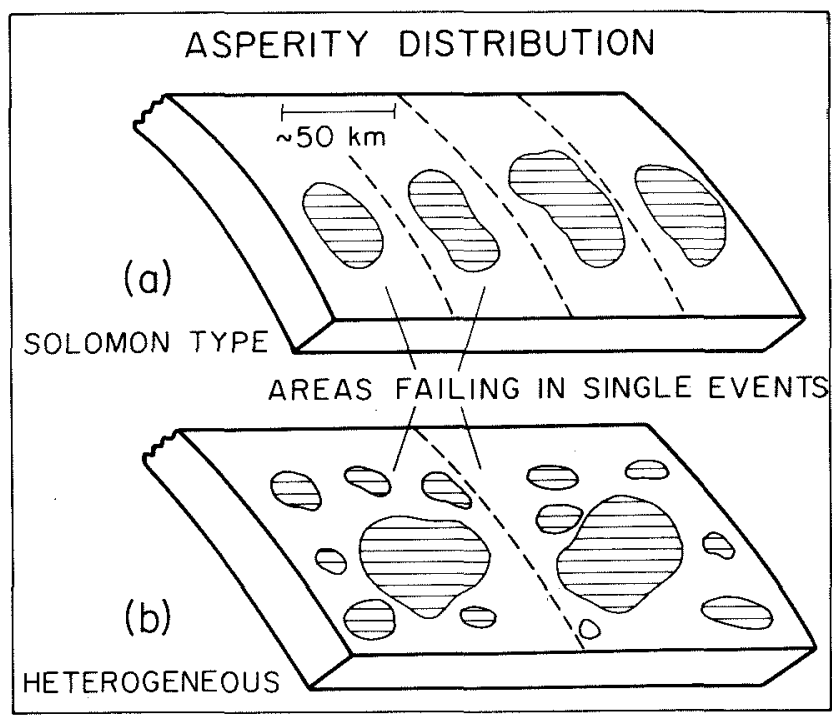

Figure 3. Asperity mode1 representation of coupling on the plate interface in subduction zones. The Solomon Islands region has a uniform distribution of comparable size zones of coupling. Other regions such as the Japan Trench and Kurile Islands have a more heterogeneous stress distribution like that shown in (b). (After Lay and Kanamori, 1980).

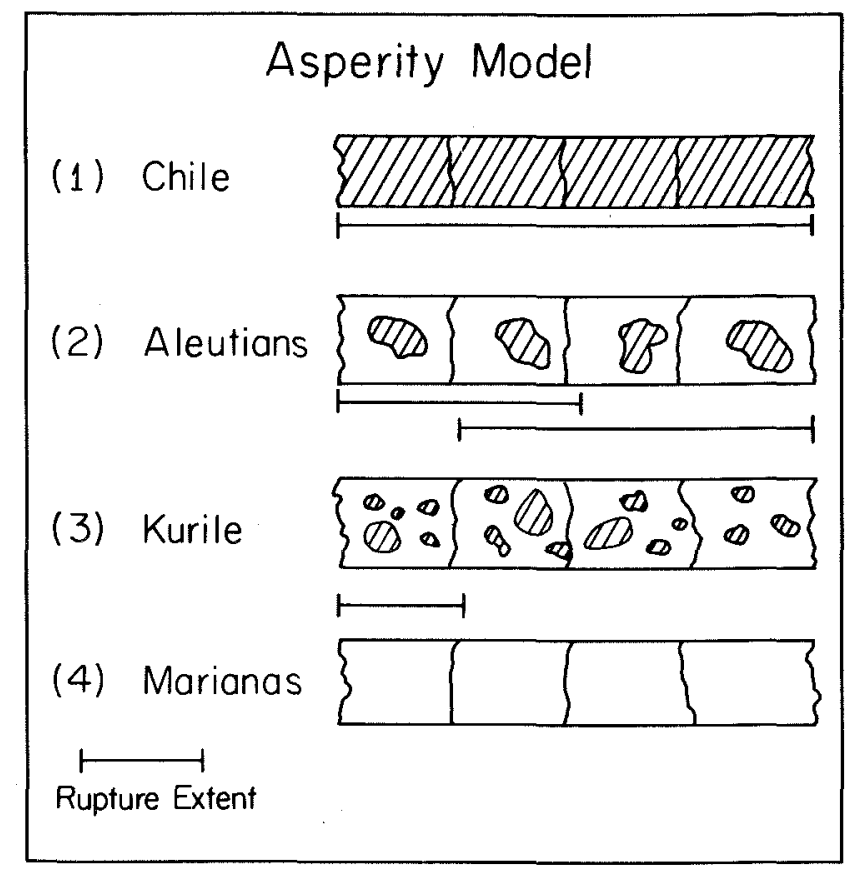

Figure 4. An asperity model indicating the different nature of stress distribution in each subduction zone category. The hatched areas indicate the zones of strong coupling.

variation in asperity size inhibits efficient loading of adjacent large asperities, as much of the load is alleviated by failure of smaller asperities. When the smaller asperities fail, the magnitude of the stress increment induced on adjacent areas is sma11, and stress builds up on the larger asperities gradually. Thus, a heterogeneous stress distribution is not likely to generate very large ruptures or multiple events. The strength of coupling on the fault is governed by the product of the area of contact and the average stress on the contact zone, with large strength resulting from large asperity area and high friction coefficient or asperity breaking stress. In the presence of aseismic slip or weak plate coupling the asperity contact area is small.

In the framework of this model, a possible interpretation of the nature of stress distribution in each subduction zone category summarized in Table 2 may be schematically given as in Figure 4. For the Chile-type behavior, the 1ithospheric plates are strongly coupled, and the asperity distribution is essentially unfform over the entire contact zone. Rupture occurs throughout the region in great events due to this uniformity, with the observed complexity of these ruptures stemming from their large size and presence of some lateral segmentation which slightly delays the stress release. Such complexity in large events rupturing across blocklike source regions has been proposed by Nagamune [1978]. The Chile-type zones have 
relatively simple, geometrically uniform subduction regimes, a condition which is probably favorable for developing uniform stress levels and effective asperity interaction.

Slightly smaller, but still relatively homogeneous asperity distributions are indicated for Aleutians-type zones. Here, the failure of the larger asperities effectively loads adjacent zones causing some large ruptures. Frequently, conditions are not favorable for immediate triggering of adjacent subzones, either due to the stress distribution being heterogeneous due to previous events in adjacent regions or due to stress barriers segmenting the trench, and smaller ruptures occur, possibly as doublets. At other times stress conditions are relatively uniform, with adjacent large asperities, which may fail together producing atypically large ruptures. The subduction regimes are relatively uniform for these regions as well as for the Chile-type zones, though the influence of transverse segmentation appears to be stronger in this case.

For the Kurile-type rupture mode there are numerous small asperities within a given subzone. Failure of the larger of these leads to failure throughout the subzone, but because of the relatively small size of the asperities, the stress increments communicated to adjacent zones are inadequate to cause larger rupture propagation. The heterogeneous stress distribution produces complicated ruptures and foreshock-aftershock activity as numerous sma11 and intermediate size asperities fail along with larger ones. Though the transverse boundaries in this case may be fairly strong, delimiting the rupture zones, the heterogeneity of the stress distribution inhibits large rupture development as wel1. For the zones in Central Chile, Peru, the New Hebrides, and Middle America, the subduction of large transverse structures may partially account for the irregular stress distribution. For the Japan Trench and Kurile Islands regions, the large amount of aseismic slip may reflect the lack of large, uniform asperities.

The final category is the Marianas-type behavior for which there are no large asperities and hence no large earthquakes. There is relatively weak coupling on the fault plane and extensive aseismic slip.

In this model, an important factor is physical segmentation of the trench caused by transverse structures on the subducting or overriding plates and geometric irregularities in the subduction zone. Such boundaries commonly delimit large failure zones, apparently functioning as barriers to lateral rupture propagation. The other dominant factor is the nature of coupling on the fault plane, which is influenced by the mechanical properties of the plates, the breadth and geometry of the contact zone, age of the subducting slab, and previous rupture history in the zone.

\section{Numerical Simulation}

In order to simulate the types of rupture sequences observed along subduction zones, we have adopted a simple fault model based on asperity distributions and interactions, as illustrated in Figure 5. The fault zone consists of a number of subfaults of uniform size, with relative strengths selected randomly from a normal distribution characterized by $a$ mean strength $\bar{s}$ and a standard deviation $\Sigma$. A uniform regional loading stress on the system as well as incremental stresses induced stepwise when adjacent subfault failures occur are applied to each subfault. The regional loading stress has the form

$$
\sigma_{o}=\sigma_{o o}+\alpha t
$$

The subfault stresses are then given by

$$
\sigma_{i}=\sigma_{0}+\Delta \sigma_{i}
$$

where $\Delta \sigma_{i}$ is the stress increment due to failure of adjacent subfaults. We select a simple form of subfault interaction governed by an interaction parameter $\mathrm{c}$ :

$$
\Delta \sigma_{i}=c \cdot s_{j} / d_{i j}
$$

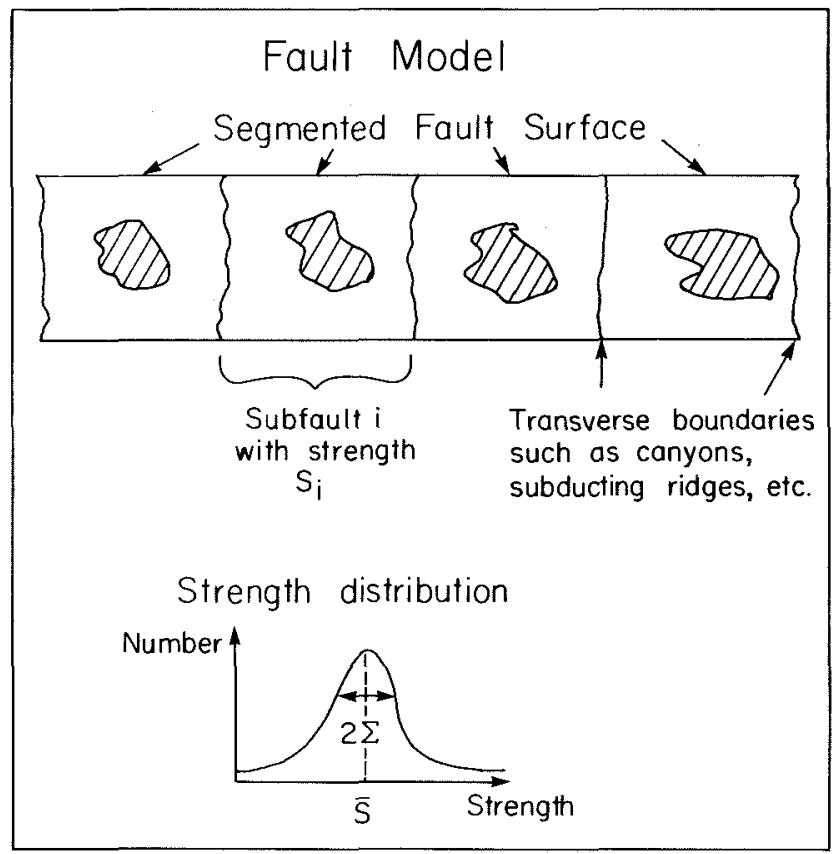

Figure 5. The fault model adopted for this study. The fault is segmented into subfaults, each with its own strength of coupling. The subfault strengths are selected randomly from a Gaussian distribution with mean strength $\bar{s}$ and standard deviation $\Sigma$. 
where $S_{j}=$ the stress drop of the falled block, and $d_{i j}$ is the distance to the failed region. We assume that the stress drop is equal to the strength assigned to the subzone. The question of whether the subfault interaction is a static or a dynamic effect is not addressed in this simple model. When the subfault stress exceeds the assigned strength the subfault fails, and the stress increment induced on adjacent zones is computed according to (3) in the same time step. Stress increments due to any additional failures are then computed and applied throughout the zone until all subfault stresses are below their strengths, at which time the falled zones are reassigned their previous strengths and the next time step is performed. This model is very similar to one analyzed by Ito [1980], though we adopt a different form of subfault interaction. Deterministic experimental and numerical fault models have frequently been adopted in simulations of seismicity, as reviewed by Cohen [1979], yet this very simple model reproduces many of the general characteristics observed in more sophisticated models. Time dependent effects are not included in this model, though they clearly exist in reality and may influence long term behavior of a region.

The parameters that govern the extent of rupture in this fault model are the range in strengths along the zone controlled by $\Sigma$, and the interaction parameter $c$. These parameters do not in general affect the resulting seismicity patterns in an identical manner, though cases can be found where their effects are similar. Increasing the interaction produces sequences of large ruptures with regular recurrence, quickly suppressing the effects of variable strength. The physical interpretation of this model is as follows. Subdivision of the fault zone into subfaults of somewhat independent behavior is suggested by the observed physical segmentation of subduction zones, and allows us to introduce stress barriers between subfaults by varying the asperity interaction along the fault. The variability in strength of the subfaults corresponds to variations in amount of seismic slip, subducted topography, and convergence rate along a given zone. The interaction parameter incorporates the efficiency with which failure of a particular zone induces stress increments on adjacent regions, corresponding to the size distribution of asperities. Thus, low $c$ reflects weak triggering interaction which is associated with heterogeneous asperity size distribution.

Figure 6 shows some representative earthquake sequences generated by this model in which the interaction parameter is varied, but the initial random strength distribution is not. For each case $c$ is constant throughout the trench. The vertical axis in each figure represents time and the horizontal axis represents position along the fault, thus each column shows the failure history of a given subfault, with circles marking the time of failure. In Figure $6 a$ there is no
Model Earthquake Sequences

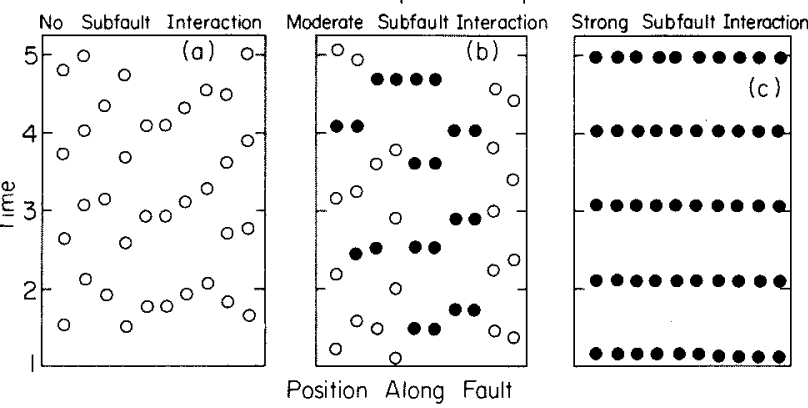

Figure 6. Earthquake sequences generated with the fault model for a fixed value of $\Sigma$, and variable subfault interaction parameter, c. In (a) $c=0.0$, and the subfaults are completely independent. In (b) $c=0.05$, and frequent clustering and occasional long ruptures occur. In (c) $c=0.15$ and long ruptures repeatedly rupture the entire fault. Solid circles indicate subzone failures that cluster in time.

interaction between subfaults, the random distribution of strengths governs the failure history and variation in recurrence interval along the trench. This pattern was produced with only a sma11 range in strengths (sma11 $\Sigma$ ), yet clustering of events seldom occurs. The independent behavior of individual subfaults is similar to behavior of the Kurile Islands category. Thus, the subzone scale here is on the order of 100 to $300 \mathrm{~km}$.

Even a small interaction between subfaults produces a markedly greater tendency for subzone failures to cluster in time as shown in Figure $6 \mathrm{~b}$, though well-separated subfaults show little obvious interaction. Closely related events are indicated by solid circles to clarify this clustering. Notice that a given length of fault sometimes experiences ruptures spanning only one or two subzones, but occasionally a very long rupture occurs. This temporal variation is similar to the Aleutians-type category. Unusual uniformity in stress conditions along the trench produces the very long rupture, but such events are not necessarily the norm for the regional behavior. Very strong subfault interaction produces the Chile-type pattern shown in Figure $6 \mathrm{c}$. There is regular recurrence of great earthquakes rupturing a large portion or the entire length of the fault.

Individual subduction zones tend to show distinct behavior with greater complexity than appears in the sequences shown in Figure 6 . Consider, for example, the Nankai Trough, with the extensive historic record indicated in Figure 7a. The subdivision of this zone into four segments was suggested by Ando [1975] on the basis of transverse geologic and bathymetric structures on the underthrusting and overriding plates. The margins of the zone are bounded by 

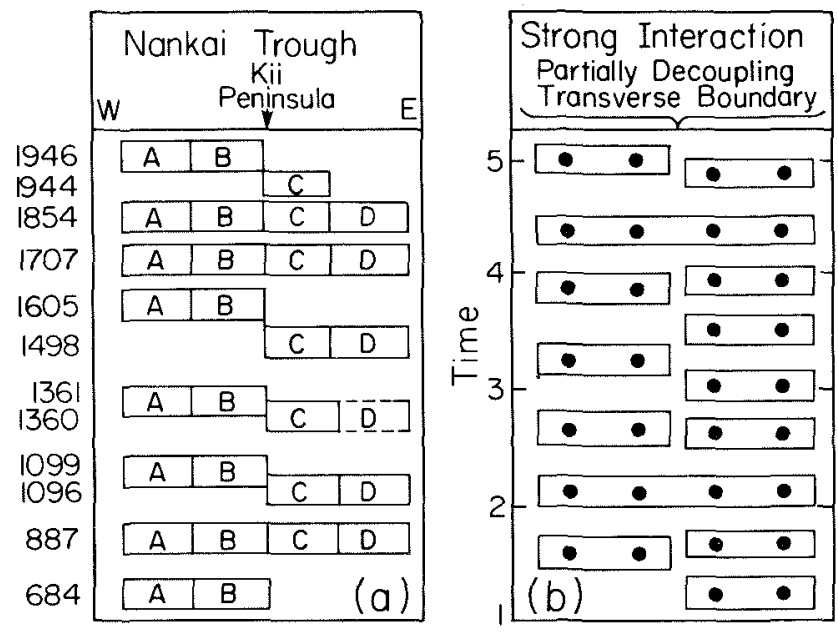

Figure 7. (a) The historical earthquake sequence in the Nankai Trough (after Ando, 1975), and (b) a model earthquake sequence generated by allowing subfault interaction to vary along the fault. A weak stress barrier separates two zones of strong subfault interaction in (b).

the Kyushu-Palau ridge to the west and the Sagami trough to the east. An interesting observation is that large earthquakes have commonly broached the inferred transverse boundaries between zones $A$ and $B$ and between $C$ and $D$, and occasionally the entire trench has ruptured together. The boundary between $B$ and $C$ lies along the southern extension of the Kii Peninsula, and although this feature is sometimes crossed by ruptures such as in 1707, it appears to exert a stronger segmenting influence than the features separating $C$ and $D$ or $A$ and $B$. In a simple attempt to incorporate this variation in subfault interaction along the trench we allow the interaction parameter $c$ to vary spatially. In particular, a weak stress barrier in the middle of the fault (between $B$ and $C$ ) is introduced, separating two regions of strong subfault interaction. The resulting pattern is shown in Figure $7 \mathrm{~b}$, and provides a reasonable approximation to the observed behavior. The weakly segmenting boundary serves to delimit the rupture zones of the doublet type events, as well as to occasionally permit total trench ruptures by allowing some triggering interaction between the adjacent regions. Additional flexibility can be introduced into the model by allowing the stress drop upon failure to vary, thus producing an irregular recurrence interval for a given subfault.

By varying the degree of subfault interaction the entire spectrum of observed great earthquake behavior can be reproduced. Subfaults interact to produce larger ruptures by triggering when the interaction parameter is large. Two basic factors influence the degree of subfault interaction; the nature of the rupture process within individual subfaults, and the presence of transverse segmentation between subfaults. The influence of these factors cannot be easily segregated. Consider the Chile-type model in Figure 6c. It is possible that the rupture occurs throughout the entire fault because there are no stress barriers segmenting the fault. Alternately, it is possible that the nature of coupling and stress release are such that triggering efficiency of adjacent zones is enhanced, overcoming whatever segmentation exists. Either explanation suggests uniformity throughout the region (with greater heterogeneity indicated for the other rupture modes). In the light of the asperity model, it is the nature of the stress distribution which principally determines the subfault interaction, however, the presence of transverse stress barriers probably modifies the loading of adjacent asperities as we11.

\section{Discussion}

The fault model presented above is not intended to reproduce the detailed seismic record of any particular zone, rather it highlights the dominant parameters producing particular rupture patterns. The regional variations in these parameters inferred from source studies and other lines of evidence are generally consistent with the asperity model results. This indicates that the asperity model provides a useful intuitive framework within which to analyze large earthquake ocurrence. As regional stress characteristics become better defined by additional detailed studies, the model may be refined, permitting a better understanding of the subduction process as well as a physical basis upon which to assess regional seismic potential.

Many aspects of the source complexity of large events can also be interpreted in the context of the barrier model proposed by Das and Aki [1977] and Aki [1979]. The quantitative aspects distinguishing the barrier and asperity models discussed by Husseini et al. [1975] and Rudnicki and Kanamori [1981], do not have adequate resolution in the seismic record to discriminate which model is more appropriate for the rupture process in great earthquakes. Lacking detailed resolution of the state of stress on the fault plane and physics of the rupture process, we have implicitly incorporated aspects of both models into the fault model presented here, including the regional asperity type stress concentrations which dominate the behavior of fault subzones, and the effects of lateral variations in asperity interaction by which we can introduce stress barriers modifying the rupture process. Both factors contribute to the occurrence of large ruptures, and merging various aspects of each model may yield a better understanding of the subduction process in the future, particularly of the triggering phenomena. Brune [1978] discussed 
the difficulties in assessing seismic hazard due to the potential for triggering interaction between adjacent zones. This aspect of subfault interaction is clearly reflected in the temporal variation of rupture extent observed in some regions.

The nature of coupling on the fault plane appears to be influenced by the history of subduction. Figure 8 reproduces the evolutionary subduction model proposed by Kanamori [1977] . Shallow dipping, broad, strongly coupled zones such as in Southern Chile and Alaska produce extensive ruptures. The thrust zone may be weakened and partially decoupled by repeated fracturing, yielding smaller rupture lengths as in the Kurile Islands and Japan Trench. Large normal events such as the 1933 Sanriku earthquake in the Japan Trench may represent a transition to

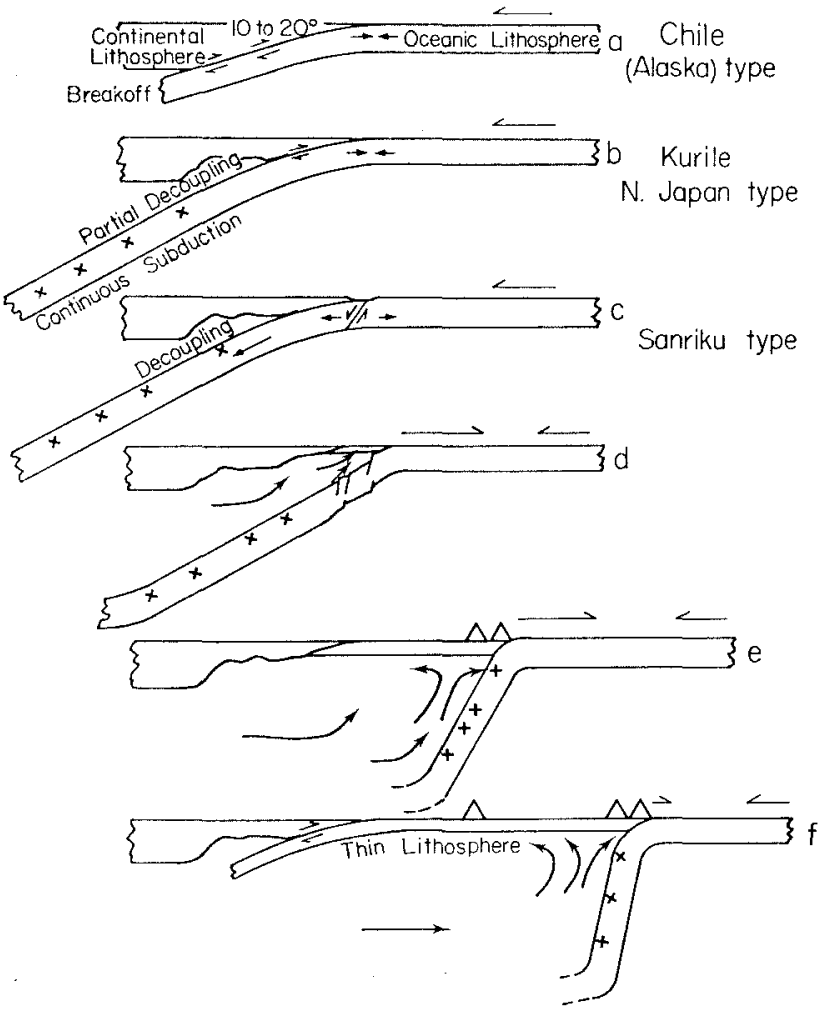

Figure 8. The evolutionary subduction model proposed by Kanamori, 1977. (a) Strong coupling between oceanic and continental lithospheres results in great earthquakes and break off of the subducting 1ithosphere at shallow depths. (b) Partial decoupling results in smqller earthquakes and continuous subduction. (c) Further decoupling results in aseismic events and intraplate tensional events. (d) Sinking plate results in retreating subduction and formation of a new thin 1ithosphere. (e) Episodic retreat and formation of ridges. (f) Decelerated retreat and commencement of new subduction. tensional stress in the slab and complete decoupling of the plate interface which may result in the development of back-arc basins by trench retreat. The variations in structure of the sedimentary wedges, upper slope basins, and terraces in the trench, which correlate with maximum rupture lengths, may reflect the transition between zones of strong and weak coupling on the fault plane.

Ruff and Kanamori [1980] tested correlations between coupling on the fault, parameterized by regional maximum earthquake magnitudes, with other parameters of the subduction zone. They found that convergence rate and lithospheric age correlate with coupling. It was also determined that penetration depth correlates with 1ithospheric age and contact width with convergence rate, results compatible with work done by Isacks et al. [1968], Vlaar and Wortel [1976], and Wortel and Vlaar [1978] • These correlations suggest that large earthquake generation correlates with interface geometry or with age and rate in some other manner. Ruff and Kanamori [1980] suggest a qualitative model in which convergence rate and lithospheric age determine the horizontal and sinking rates of the slab, thus controlling the dip of the Benioff zone and normal stress distribution on the fault plane. The area of coupling may change due to reducing cross section with increasing dip or degradation of the interface. This mode1 indicates that the downgoing plate determines the stress state in the $s 1 a b$ and on the interface, as suggested in the evolutionary subduction model of Kanamori [1977].

\section{Conclusions}

Regional variations in large shallow earthquake fault lengths between circum-Pacific subduction zones are used to infer the bastc stress distribution in each zone. The degree of coupling and segmentation of the stress regime by transverse boundaries influence the development of large rupture dimensions. Very strong coupling on the fault plane overcomes the effect of lateral segmentation to produce regularly recurring great earthquakes in Southern Chile, Alaska, Southern Kamchatka, and possibly in the Central Aleutians. These zones have predominantly seismic slip and generate large multiple ruptures by sequential failure of adjacent subzones of relatively uniform stress distribution. The variability of rupture length in the Western Aleutians, Colombia, and Nankai Trough regions reflects interaction between coupling and segmentation, and indicates the need to understand these factors when assessing regional seismic potential. The Solomon Islands and Nankai Trough have distinctive large earthquake clustering, perhaps reflecting uniformity in the stress regime along these zones, though transverse boundaries modify the development of large ruptures. The seismic 
record indicates that zones with substantial aseismic slip and heterogeneous stress distribution generate moderate size, but complex ruptures, as in the Japan Trench, Central Chile, Peru, and the Kurile Islands. The large amount of aseismic slip and weak coupling in these zones may result from progressive weakening of the fault contact as subduction progresses. The New Hebrides and Middle America appear to have small scale but fairly uniform stress distributions, producing occassional clustering of events, but no great earthquakes. A simplified fault model incorporating aspects of the asperity and barrier models has been shown to support the inferences of the state of stress in each region.

Acknowledgments. We appreciate helpful suggestions made by $\mathrm{T}$. Wallace and $\mathrm{J}$. Ebel and the anonymous reviewers. Research supported by the Earth Sciences Section National Science Foundation Grant No. (EAR 78-14786) and United States Geological Survey Contract No. (14-08-0001-18321). One of the authors, T. L., was supported by a National Science Foundation Graduate Fellowship. Contribution No. 3492, Geological and Planetary Sciences, Seismologica1 Laboratory, California Institute of Technology, Pasadena, California 91125.

\section{References}

Abe, K., Tectonic implications of the large Shioya-0ki earthquakes of 1938, Tectonophysics, $41,269-289,1977$.

Aki, K., Characterization of barriers on an earthquake fault, J. Geophys. Res., 84, 6140-6148, 1979.

Ando, M., Source mechanisms and tectonic significance of historical earthquakes along the Nankai Trough, Japan, Tectonophysics, 27, 119-140, 1975.

Boatwright, J., Preliminary body-wave analysis of the St. Elias, Alaska earthquake of February 28, 1979, Bu11. Seismo1. Soc. Amer., 70, 419-436, 1980 .

Brune, J. N., Implications of earthquake triggering and rupture propagation for earthquake prediction based on premonitory phenomena, Proceedings of conference IV: Fault mechanics and its relation to earthquake prediction, USGS Open File Report \#78-380, $71-82,1978$.

Byerlee, J. D., Static and kinetic friction of granite under high stress, Int. J. Rock Mech. Min. Sc1., 7, 577-582, 1970 .

Carr, M. J., R. E. Stoiber and C. L. Drake, The Segmented nature of some continental margins, in C. A. Burk and C. L. Drake, (eds.), The Geology of Continental Margins, Springer-Velag, 105-114, 1974 .

Chung, Wai-Ying and $\mathrm{H}$. Kanamort, Source process and tectonic implications of the Spanish deep focus earthquake of March 29, 1954, Phys. Earth Planet. Interiors, 13, 85-96, 1976.
Chung, Wai-Ying and H. Kanamori, Subduction process of a fracture-zone and aseismic ridges - the focal mechanism and source characteristics of the New Hebrides earthquake of January 19, 1969 and some related events, Geophys. J. R. Astr. Soc., 54, 221-240, 1978 .

Chung, Wai-Ying and $\mathrm{H}$. Kanamori, A mechanical model. for plate deformation associated with aseismic ridge subduction in the New Hebrides arc, Tectonophysics, 50, 29-40, 1978b.

Cohen, S. C., Numerical and laboratory simulation of fault motion and earthquake occurrence, Reviews Geophy. Space Phys., 17, 61-72, 1979.

Das, S. and K. Aki, Fault planes with barriers; A versatile earthquake model, J. Geophys. Res., 82, 5658-5670, 1977.

Ebel, J. E., Source processes of the 1965 New Hebrides Islands earthquakes inferred from teleseismic waveforms, Geophys. J. R. astr. Soc., $63,381-404,1980$.

Fedotov, S. A., Regularities of the distribution of strong earthquakes of Kamchatka, the Kurile Islands, and northeastern Japan, Trudy Inst. Fiz. Zemli Akad. Nauk. SSSR, 36, 66-93, 1965 (in Russian).

Fukao, Y., Source process of a large deep-focus earthquake and its tectonic implications - The western Brazil earthquake of 1963, Phys. Earth Planet. Interiors, $\underline{5}, 61-76,1972$.

Fukao, Y. and M. Furumoto, Foreshocks and multiple shocks of large earthquakes, Phys. Earth Planet. Interiors, 10, 355-368, 1975 .

Fukao, Y. and M. Furumoto, Stress drops wave spectra and recurrence intervals of great earthquakes - Implications of the Etorofu earthquake of 1958 November 6, Geophys. J. R. astr. Soc., 57, 23-40, 1979.

Husseini, M. I., D. B. Jovanovich, M. J. Randall and L. B. Freund, The fracture energy of earthquakes, Geophys. J. R. astr. Soc., 43, 367-385, 1975 .

Imamura, A., On the seismic activity of central Japan, Jap. J. Astron. Geophys., $\underline{6}$, $119-137,1928$.

Imamura, A., Theoretical and Applied Seismology, Marozen, Tokyo, 358pp., 1937.

Isacks, B., J. Oliver and L. R. Sykes, Seismicity and the new global tectonics, J. Geophys. Res., 73, 5855-5899, 1968.

Ishida, M. and H. Kanamori, The foreshock activity of the 1971 San Fernando, California earthquake, Bu11. Seismo1. Soc. Amer., 68, $1265-1279,1978$.

Ishida, M. and H. Kanamori, Temporal variation of seismicity and spectrum of small earthquakes preceding the 1952 Kern County, California earthquake, Bull. Seismol. Soc. Amer., 70, 509-527, 1980 .

Ito, K., Periodicity and chaos in great earthquake occurrence, J. Geophys. Res., 85, 1399-1408, 1980.

Jones, L. M. and P. Molnar, Some 
characteristics of foreshocks and their possible relationship to earthquake prediction and premonitory slip on faults, J. Geophys. Res., 84, 3596-3608, 1979.

Kanamori, H., Seismological evidence for a 1ithospheric normal faulting - The Sanriku earthquake of 1933, Phys. Earth Planet. Interiors, 4, 289-300, 1971a.

Kanamori, H., Great earthquakes at island ares and the 1ithosphere, Tectonophysics, 12, 187-198, 1971b.

Kanamori, H., Selsmic and aseismic slip along subduction zones and their tectonic implications, in M. Talwani and W. C. Pitman III, (eds.), Island Arcs, Deep Sea Trenches and Back-Arc Basins, Maurice Ewing Series, I, 163-174, AGU, Washington, D. C., 1977.

Kanamori, H., Use of seismic radiation to infer source parameters, Proceedings of conference IV: Fault mechanics and its relation to earthquake prediction, USGS Open File Report 78-380, 283-318, 1978a.

Kanamori, $H_{.}$, Nature of seismic gaps and foreshocks, Proceedings of conference VI: Methodology for identifying seismic gaps and soon to break gaps, USGS Open File Report 78-943, 319-334, 1978b.

Kanamori, H., The nature of seismicity patterns before major earthquakes, 1981 (this volume).

Kanamori, H. and G. S. Stewart, Seismologica1 aspects of the Guatemala earthquake of February 4, 1976, J. Geophys. Res., 83, 3427-3434, 1978.

Kelleher, J. A., Space-time seismicity of the Alaska-Aleutian seismic zone, J. Geophys. Res., 75, 5745-5756, 1970.

Kelleher, J. A., Rupture zones of large South America earthquakes and some predictions, J. Geophys. Res., 77, 2087-2103, 1972.

Kelleher, J. and $\mathrm{W}$. McCann, Bathymetric highs and the development of convergent plate boundaries, in M. Talwani and $W$. C. Pitman III, (eds.), Island Arcs, Deep Sea Trenches and Back-Arc Basins, Maurice Ewing Series, I, 115-122, AGU, Washington, D.C., 1977.

Kelleher, J. and W. McCann, Buoyant zones, great earthquakes, and unstable boundaries of subduction, J. Geophys. Res., 81, 4885-4896, 1976.

Kelleher, J. and J. Savino, Distribution of seismicity before large strike slip and thrust-type earthquakes, J. Geophys. Res., 80, 260-271, 1975.

Kelleher, J., J. Savino, H. Rowlett and W. McCann, Why and where great thrust earthquakes occur along island arcs, J. Geophys. Res., 79, 4889-4899, 1974 .

Kelleher, J., L. Sykes and J. Oliver, Possible criteria for predicting earthquake locations and their application to major plate boundaries of the Pacific and the Caribbean, J. Geophys. Res., 78, 2547-2585, 1973.

Lay, T. and H. Kanamori, Earthquake doublets in the Solomon Islands, Phys. Earth Planet. Int., 21, 283-304, 1980 .
Lay, T. and $H$. Kanamori, The asperity model and the nature of great earthquake occurrence, in preparation, 1981 .

McCann, W. R., S. P. Nishenko, L. R. Sykes and J. Kraus, Seismic gaps and plate tectonics: Seismic potential for major boundaries, Pageoph., 117, 1087-1147, 1980.

Miyamura, S., S. Omote, R. Teisseyre and E. Vesanen, Multiple shocks and earthquake series pattern, Int. Inst. Seismol. Earthquake Eng. Bu11., 2, 71-92, 1965.

Mogi, K., Development of aftershock areas of great earthquakes, Bu11. Earthquake Res. Inst., 46, 175-203, 1968a.

Mogi, K., Sequential occurrences of recent great earthquakes, J. Phys. Earth, 16, 30-36, $1968 \mathrm{~b}$.

Mogi, K., Some features of recent seismic activity in and near Japan (2) Activity before and after great earthquakes, Bu11. Earthquake Res. Inst., 47, 395-417, 1969a.

Mogi, K., Relationship between the occurrence of great earthquakes and tectonic structures, Bu11. Earthquake Res. Inst., 47, 429-451, 1969b.

Nagamune, T., Source regions of great earthquakes, Geophys. Mag., 35, 333-399, 1971.

Nagamune, T., Tectonic structures and multiple earthquakes, Zisin: J. Seismo1. Soc. Japan, 31, 457-468, 1978 (in Japanese).

Nishenko, S. and W. McCann, Large thrust earthquakes and tsunamis: Implications for the development of fore arc basins, J. Geophys. Res., 84, 573-584, 1979.

Ria1, J. A., The Caracas, Venezuela earthquake of July 1967: A multiple source event, J. Geophys. Res., 83, 5405-5414, 1978.

Rudnicki, J. W. and H. Kanamori, Effects of fault interaction on moment stress drop and strain energy release, in press, 1981.

Ruff, L. and H. Kanamori, Seismicity and the subduction process, Phys. Earth Planet. Int., 23, 240-252, 1980 .

Scholz, C. H. and J. T. Engelder, The role of asperity indentation and ploughing in rock friction, I. Asperity creep and stick slip, Int. J. Rock Mech. Min. Sci., 13, 149-154, 1976.

Seno, T., The instantaneous rotation vector of the Philippine sea plate relative to the Eurasian plate, Tectonophysics, 42, 209-226, 1977.

Spence, W., The Aleutian arc: tectonic blocks, episodic subduction, strain diffusions and magma generation, $\mathrm{J}$. Geophys. Res., 82, 213-230, 1977.

Stewart, G. S., E. C. Chael and K. C. McNally, The 1978 November 29 Oaxaca, Mexico earthquake - a large single event, Geophy. J. R. Astron. Soc., in press, 1980 .

Stewart, G. S. and H. Kanamori, Complexity of rupture propagation in large earthquakes (abstract), Trans. AGU, 59, 1127, 1978.

Sykes, L. R., Aftershock zones of great 
earthquakes, seismicity gaps, and earthquake prediction for Alaska and the Aleutians, J. Geophys. Res., 76, 8021-8041, 1971.

Sykes, L. R., J. B. Kisslinger, L. House, J. N. Davies and K. H. Jacob, Rupture zones of great earthquakes, Alaska-Aleutian arc, 1784-1980, Science, in press, 1981.

Trifunac, M. D. and J. N. Brune, Complexity of energy release during the Imperial Valley, California earthquake of 1940 , Bu11. Seismol. Soc. Amer., 60, 137-160, 1970.

Utsu, T., Space-time pattern of large earthquakes occurring off the Pacific coast of the Japanese Islands, J. Phys. Earth, 22, 325-342, 1974. Uyeda, S. and H. Kanamori, Back-arc opening and the mode of subduction, J. Geophys. Res., 84, 1049-1061, 1979.

Vlaar, N. and M. Wortel, Lithospheric aging, instability, and subduction, Tectonophysics, 32, 331-351, 1976 .
Vogt, P. R., Subduction and aseismic ridges, Nature, 241, 189-191, 1973.

Vogt, P. R., A. Lowrie, D. Bracey and R. Hey, Subduction of aseismic oceanic ridges: Effects on shape, seismicity and other characteristics of consuming plate boundaries, Geol. Soc. Amer. Spec. Paper, 172, 59p., 1976.

Wesson, R. L. and W. L. E1lsworth, Seismicity preceding moderate earthquakes in California, J. Geophys. Res., 78, 8527-8546, 1973.

Wortel, M. and N. vlaar, Age-dependent subduction of oceanic lithosphere beneath western South America, Phys. Earth Planet. Interiors, 17, 201-208, 1978 .

Wu, F. T. and H. Kanamori, Source mechanism of February 4, 1965, Rat Island earthquake, J. Geophys. Res., 78, 6082-6092, 1973.

Wyss, M. and J. Brune, The Alaska earthquake of 28 March 1964: A complex multiple rupture, Bul1. Seismol. Soc. Amer., 57, 1017-1023, 1967. 